\title{
P. PREETHU
}

\section{Twilight}

The Grove 21 (2014)

On moonlit nights,

I travel in dreams, climb

Up the juniper, seeking

The tip where She is.

Adi Shakti, Adi Shakti, Adi Shakti, Namo Namo!

On scorching days,

I travel awake, dig

Down to the roots,

Where she is.

She, who wasn't born, Guillotined before oleander And castor -sap and oilCould take her away.

Safe from prying hands Which pamper and hurt, Denuding eyes, thorns of Love, splash of acid devouring Raw flesh, being weighed Against gold, pricked by vultures, Bruised, beaten, put in flames, Slogged, isolated, orphaned-

I seek myself, at both ends, The truth of what I call 'I', Stranded at twilight, I know not Whom to trust- to bygone sun, Or the approaching shadows. 
'Twilight' is a poem about the identity crisis faced by an average Indian woman. Religious tradition speaks of her as Shakti (goddess) who is the primordial cosmic energy representing the divine feminine. At the same time, she has to suffer a lot of atrocities in the patriarchal society, ranging from female infanticide to death. Juniper symbolizes the journey in which selfhood is not compromised. In dreams of a glorious past, she chants the Sakti mantra (hymn) and invokes the goddess in the highest tip of the tree of selfhood while the cruel reality binds her to the roots. 